\title{
Strategies for Improving Parental Involvement in Acquisition of Literacy Skills among Pupils in Primary Schools in Akithi Division, Tigania West District, Kenya
}

\author{
James Mwenda Murungi, George Mungiria Muthaa*, Linus Micheni, Elias Eric Mwenda \\ Department of Education, Chuka University, Chuka, Kenya \\ Email: "gmuthaa@yahoo.com
}

Received 2 February 2014; revised 6 March 2014; accepted 14 March 2014

Copyright (C 2014 by authors and Scientific Research Publishing Inc.

This work is licensed under the Creative Commons Attribution International License (CC BY).

http://creativecommons.org/licenses/by/4.0/

(c) (i) Open Access

\begin{abstract}
Literacy is the basis for most school learning, and one of the surest predictors of academic achievement. Studies indicate that parents in Kenya are not actively involved in their children's literacy acquisition process. This study sought to establish the possible strategies that could be put in place to enhance parental involvement in the acquisition of literacy skills. The study was carried out in Akithi Division, Tigania West District, Kenya. Descriptive survey research design was used to carry out this study. Data collection was done using questionnaires and interview schedules. The study suggests that school administrators need to formulate clear policy guidelines on the involvement of parents in the literacy development of their children.
\end{abstract}

\section{Keywords}

Strategies; Parental Improvement; Acquisition; Literacy Skills

\section{Introduction}

Parents play a vital role in their children's emerging literacy. Savage and Egerton [1] observe that as the child's first and most important teachers in the preschool years, parents are crucial to the awakening of children's literacy. Many parents may not actively set out to teach children how to read. Pappas [2] notes that a variety of experiences, trips and visits, books and pictures, stories told and questions answered all contribute to reading ability, for they furnish that background of spoken language so vital to the development of understood vocabulary.

*Corresponding author.

How to cite this paper: Murungi, J.M., et al. (2014) Strategies for Improving Parental Involvement in Acquisition of Literacy Skills among Pupils in Primary Schools in Akithi Division, Tigania West District, Kenya. Open Journal of Social Sciences, 2, 250-255. http://dx.doi.org/10.4236/iss.2014.24026 
Savage and Egerton [1] further suggest that parents may provide a stimulating environment, read frequently to their children, engage in conversation and word play, respond to their children's requests for information, and help their children begin to understand how literacy fits into their lives.

Literacy is one of the subject areas where parents have the simple tools such as books and other reading materials to become involved and to make a difference. Senechal and LeFevre [3] observe that of all school subjects, reading has been found to be most sensitive to parental influences. Simple interactions, such as being read to and exposure to books, magazines, newspapers and environmental print, impact children's progress in learning to read [4]. Parents are the prime educators until a child attends nursery school or starts primary school and they remain a major influence on their children's learning throughout school and beyond.

However, studies indicate that children in Kenya are lagging behind in literacy skills. Uwezo [5] in the Annual Learning Assessment-Kenya 2010 found that children in Kenyan primary schools are poorly grounded in literacy skills. Literacy is conceptualized as composed of multiple dimensions that cross the boundaries between oral and written language, that affect each other reciprocally and that are greatly influenced by the learning opportunities provided to children at home and school [6].This study sought to determine strategies for improving parental involvement in the acquisition of literacy skills.

\subsection{Statement of the Problem}

Literacy is critical to a child's academic development. However, UNESCO and Uwezo-Kenya reports have questioned the level of literacy skills among pupils in Kenyan primary schools. This study sought to establish the possible strategies that can be put in place to enhance parental involvement in the acquisition of literacy skills among pupils in primary schools in Akithi Division, Tigania West District, Kenya.

\subsection{Research Objective}

This study sought to achieve the following objective:

To determine the strategies that can be used to enhance parental involvement in the acquisition of literacy skills among pupils in primary schools.

\subsection{Methodology of the Study}

Using the descriptive survey among pupils, teachers and patents, this study intends to explore methods to enhance the involvement of parents in acquisition of their children's literacy skills in Kenya. The study was conducted in eight public primary schools in Akithi Division, Tigania West District, Kenya. The accessible population was 1581 subjects made up of 1031 standard eight pupils, 144 lower primary school class teachers and 406 parents in the School Management Committees (SMC) in 29 public primary schools in Akithi Division. Eight schools were selected through simple random sampling to participate in the study. Schools were assigned numbers 1 to 29. Uniform balls were labeled numbers 1, 2, .., 29 representing each school, and placed in a container that allowed for thorough mixing of the balls. After mixing, a single ball was selected then the balls were mixed again and a second ball selected without looking. The same procedure was repeated until eight balls representing the sampled schools were selected. All the standard eight pupils, a class teacher and the parents' representative in the SMC from each lower primary level in the sampled schools were purposively selected to participate in the study. Standard eight pupils were selected since they possess language skills that would enable them to understand and respond to items on the questionnaire. The pupils also have knowledge about parental involvement from their own experiences. Lower primary school class teachers were considered because they handle pupils at a time when they acquire basic literacy skills while SMC's were interviewed because they form an important linkage between parents and schools.

Questionnaires and an interview schedule were used for data collection. The researcher ensured content validity through the expert judgment of the supervisors as advanced Mugenda and Mugenda [7]. The experts assessed the effectiveness of each item in the instruments to achieve the intended outcomes. Data was analyzed using percentages and frequencies and presented using tables and charts.

\section{Results and Discussions}

\subsection{Demographic Information}

Section one of the pupils' questionnaire required respondents to state their gender, the type of family by compo- 
sition and the highest level of education attained by their parents. The teachers' questionnaire required respondents to state their gender, academic qualification and their teaching experience. To enable the researcher establish the relationship between gender and participation in literacy acquisition, the researcher sought to establish the gender of the pupils, teachers and parent who participated in the study and the results are reflected on Table 1 .

Information in Table 1 shows that female respondents made up $75 \%$ while males made up $25 \%$ of the respondents. The pupils surveyed comprised $53.7 \%$ males and $46.3 \%$ females. Among the parents, female respondents made up $62.5 \%$ while the males made up $37.5 \%$ of the respondents. This shows that the number of female parents who participated in the study was higher than that of the male parents.

\subsection{Family Status}

The researcher collected data concerning the kind of family in which the respondents were brought up in terms of who they lived with. The results are revealed in Table 2.

Information in Table 2 shows that respondents who lived with both their parents were the majority at $68.3 \%$ followed by those who lived with their mothers only at $18.8 \%$. Respondents who lived with their guardians comprised $8.7 \%$ of the respondents while those who lived with their fathers only were the least at $4.2 \%$. This shows that majority of the respondents lived with at least one parent while others (8.7\%) lived with their guardians and therefore had an opportunity to receive assistance in acquiring foundational literacy skills at home.

\subsection{Strategies to Enhance Parental Involvement in Acquisition of Literacy Skills}

Teachers and pupils were asked to rate the usefulness of eight (8) selected strategies in enhancing parental involvement in the literacy acquisition process for their children. Table 3 presents the teachers' and pupils' opinion about the various strategies.

Information in Table 3 indicates that a good number of the selected strategies were rated as very useful in enhancing parental involvement in literacy acquisition by the majority of teachers and pupils. Holding of parents' meetings in school to educate them on the importance of their involvement was rated as a very useful strategy by $66.7 \%$ of teachers and $84.3 \%$ of pupils. Robb [8] observes that parents require school guidance and support to deliver home literacy.

Allowing children to carry home school library books to read to their parents was rated as moderately useful strategy by $54.2 \%$ of the teachers and as very useful strategy by $72.5 \%$ of the pupils. The respondents view on the importance of school library books agrees with the finding by Australian School Library Association (ASLA, [9]) that students in classrooms with access to school libraries achieve higher in terms of reading scores than those who do not have such access.

Table 1. Respondents' gender.

\begin{tabular}{cccc}
\hline \multirow{2}{*}{ Respondents } & Gender & Frequency & Percentage \% \\
\hline \multirow{2}{*}{ Teachers } & Males & 6 & 25 \\
& Females & 18 & 75 \\
\multirow{2}{*}{ Pupils } & Males & 154 & 53.7 \\
& Females & 133 & 46.3 \\
\multirow{2}{*}{ Parents } & Males & 9 & 37.5 \\
& Females & 15 & 62.5 \\
\hline
\end{tabular}

Table 2. Family status.

\begin{tabular}{ccc}
\hline Pupil lives with & Frequency & Percentage \\
\hline Father and mother & 196 & 68.3 \\
Father only & 12 & 4.2 \\
Mother only & 54 & 18.8 \\
Guardian & 25 & 28.7 \\
Total & 287 & 100 \\
\hline
\end{tabular}


Table 3. Teachers’ and pupils’ opinion on strategies for enhancing parental involvement.

\begin{tabular}{|c|c|c|c|c|c|c|}
\hline Strategy & Respondents & $\begin{array}{l}\text { Very } \\
\text { useful } \\
\%\end{array}$ & $\begin{array}{l}\text { Moderately } \\
\text { useful } \\
\quad \%\end{array}$ & $\begin{array}{l}\text { No } \\
\text { opinion } \\
\%\end{array}$ & $\begin{array}{l}\text { Lowly } \\
\text { useful } \\
\%\end{array}$ & $\begin{array}{l}\text { Not useful } \\
\text { at all } \\
\%\end{array}$ \\
\hline \multirow{2}{*}{$\begin{array}{l}\text { Holding parents' meetings in school to educate } \\
\text { parents on the importance of their involvement }\end{array}$} & Pupils & 84.3 & 14.6 & 0.0 & 0.7 & 0.3 \\
\hline & Teachers & 66.7 & 33.3 & 0.0 & 0.0 & 0.0 \\
\hline \multirow{2}{*}{$\begin{array}{l}\text { Allowing children to carry home school library } \\
\text { books to read to their parents }\end{array}$} & Pupils & 72.5 & 21.6 & 1.0 & 2.4 & 2.4 \\
\hline & Teachers & 37.5 & 54.2 & 4.2 & 4.2 & 0.0 \\
\hline \multirow{2}{*}{$\begin{array}{l}\text { Having individual parents meet regularly with } \\
\text { teachers to discuss their children's progress in } \\
\text { reading }\end{array}$} & Pupils & 72.1 & 23.0 & 2.4 & 2.1 & 0.3 \\
\hline & Teachers & 79.2 & 12.5 & 4.2 & 0.0 & 4.2 \\
\hline \multirow{2}{*}{$\begin{array}{l}\text { Educating teachers on the value of working with } \\
\text { parents to improve children's performance in } \\
\text { reading and writing skills }\end{array}$} & Pupils & 81.9 & 15.3 & 0.7 & 1.7 & 0.3 \\
\hline & Teachers & 79.2 & 12.5 & 4.2 & 4.2 & 0.0 \\
\hline \multirow{2}{*}{$\begin{array}{l}\text { Encouraging parents to read to their children or to } \\
\text { listen as their children read to them }\end{array}$} & Pupils & 86.4 & 0.3 & 12.2 & 0.7 & 0.3 \\
\hline & Teachers & 45.8 & 33.3 & 4.2 & 16.7 & 0.0 \\
\hline \multirow{2}{*}{$\begin{array}{l}\text { Encouraging parents to buy extra books and } \\
\text { reading materials for their children }\end{array}$} & Pupils & 85.0 & 14.3 & 0.7 & 0.0 & 0.0 \\
\hline & Teachers & 83.3 & 8.3 & 4.2 & 4.2 & 0.0 \\
\hline \multirow{2}{*}{$\begin{array}{l}\text { Holding seminars for parents to train them on } \\
\text { how to assist their children learn how to read and } \\
\text { write }\end{array}$} & Pupils & 80.5 & 17.8 & 1.0 & 0.7 & 0 \\
\hline & Teachers & 66.7 & 20.8 & 4.2 & 4.2 & 4.2 \\
\hline
\end{tabular}

Majority of the respondents rated "having individual parents meet regularly with teachers to discuss their children's progress in reading” as a very useful strategy at $79.2 \%$ and $72.1 \%$ for teachers and pupils respectively. Clay [10] observed that parents connect with children in personal ways across time and can play a special role in helping teachers understand how their children relate to print outside the classroom.

Other strategies that were rated as very useful in enhancing parental involvement in literacy acquisition by both teachers and pupils as shown on Table 4 include: educating teachers on the value of working with parents to improve children's performance in reading and writing, encouraging parents to read to their children or to listen as their children read to them, encouraging parents to buy extra books and reading materials, holding seminars to train parents on how to assist their children learn how to read and write and requiring parents to check their children's homework. These views are reinforced by the findings by Toomey [11] that parents are often insufficiently aware of the kinds of activities that can aid their children's literacy learning. Gianzero [12] observed that parents often want to be more involved in their children's education but are uncertain how to do so. Gianzero [12] further notes that if schools want parents to be involved in the developing of their children's literacy they should provide opportunities. It is therefore the school's responsibility to generate effective parent involvement by designing strategies that seek to engage parents on a continuing basis (Gianzero, [12]).

Parents were asked to suggest strategies to enhance parental involvement in literacy acquisition. Table 4 presents strategies that were proposed by the parents.

The majority of parents (66.7\%) suggested that encouraging parents to buy extra books and reading materials for children would enhance parental involvement. Establishing school policy on involvement of parents was suggested by $54.2 \%$ of the parents while economic empowerment of parents was suggested by $50 \%$ of the respondents. $45.9 \%$ of the respondents suggested that schools should establish open days when parents can consult with teachers while requiring parents to check and sign children's homework regularly was suggested by $41.7 \%$ of the parents. Organizing parents' meetings to sensitize them on the importance of their involvement was suggested by $37.5 \%$ of the parents while another $37.5 \%$ of the respondents suggested that government should fight the sale of illegal local brews.

Pupils were given an open ended question to suggest additional strategies for enhancing parental involvement in the acquisition of literacy skills by their children. Table 5 presents an analysis of pupils' suggestions on strategies for enhancing parental involvement in literacy acquisition.

The majority (73.2\%) of the pupils suggested sensitizing of parents on the importance of education. Many (59.6\%) respondents suggested discouraging parents from engaging their children in child labour as an additional strategy for enhancing parental involvement in acquisition of literacy skills. About $47 \%$ of the pupils 
Table 4. Parents' suggestions of strategies to enhance parental involvement.

\begin{tabular}{lcc}
\hline Strategy & Frequency & Percentage \% \\
\hline $\begin{array}{l}\text { Encouraging parents to buy extra books and reading } \\
\text { materials for children }\end{array}$ & 16 & 66.7 \\
Establishing school policy on involvement of parents & 13 & 54.2 \\
Economic empowerment of parents & 12 & 50.0 \\
$\begin{array}{l}\text { Schools to establish open days when parents can consult } \\
\text { with teachers }\end{array}$ & 11 & 45.8 \\
$\begin{array}{l}\text { Require parents to check and sign children's homework } \\
\text { regularly }\end{array}$ & 9 & 41.7 \\
Government to fight the sale of illegal local brews & 9 & 37.5 \\
$\begin{array}{l}\text { Organizing parents meetings to sensitize them on the } \\
\text { importance of their involvement }\end{array}$ & 37.5 \\
\hline
\end{tabular}

Table 5. Pupils suggestions on strategies for enhancing parental involvement.

\begin{tabular}{lcc}
\hline Strategy & Frequency & Percentage \% \\
\hline Discouraging child labour & 171 & 59.6 \\
Encourage parents to discipline their children & 108 & 37.6 \\
Encourage parents to give moral support to their children & 135 & 47 \\
Encourage adult literacy classes for illiterate parents & 75 & 26.1 \\
Require parents to check children's homework & 84 & 29.3 \\
Sensitize parents on the importance of education & 210 & 73.2 \\
Control of alcoholism and drug abuse in the society & 18 & 6.2 \\
Empowering parents economically & 60 & 20.9 \\
\hline
\end{tabular}

suggested that parents should be encouraged to give moral support to their children. "Parents being encouraged to discipline their children" was suggested by $37.6 \%$ of the respondents while $26.1 \%$ of the pupils suggest that illiterate parents should be encouraged to enroll in adult literacy classes. About $20 \%$ of the pupils suggested empowering parents economically as a viable strategy for enhancing their involvement in literacy acquisition while $6.2 \%$ suggested control of alcoholism and drug abuse in the society.

Teachers were asked to state the extent to which they agreed or disagreed with the statement "schools are doing enough to enhance parental involvement in literacy acquisition”. Table 6 presents the teachers' responses.

Half of the teachers (50\%) disagreed with the statement that schools were doing enough to enhance parental involvement in literacy acquisition. $25 \%$ of the teachers agreed with the statement while $20.8 \%$ of the teachers strongly agreed with the statement.

\section{Conclusions}

Based on the findings of the study the following conclusions are drawn:

1) That schools are not making enough effort to enhance parental involvement in literacy acquisition of their children.

2) School support is crucial for the enhancement of parental involvement in acquisition of literacy skills of their children.

3) Enhancing community sensitization on the importance of parental involvement, training parents on how to help their children acquire literacy skills, discouraging child labour, encouraging parents to buy books and establishing of school policies on the involvement of parents in literacy acquisition are useful strategies for enhancing parental involvement in literacy acquisition. 
Table 6. Schools are doing enough to enhance parental involvement in literacy acquisition.

\begin{tabular}{ccc}
\hline Opinion & Frequency & Percent \\
\hline Strongly agree & 5 & 20.8 \\
Agree & 6 & 25.0 \\
Undecided & 1 & 4.2 \\
Disagree & 12 & 50.0 \\
Strongly disagree & 0 & 0 \\
Total & 24 & 100 \\
\hline
\end{tabular}

\section{Recommendations}

The following recommendations are necessary in light of the responses from the respondents and in view of the research findings.

1) It is recommended that school managers put in place clear policies on the involvement of parents in their children's acquisition of literacy skills. This could be done through the introduction of open days for parents with children in public primary schools. These open days could be dedicated to consultation between individual parents and teachers over children's progress in literacy as well as other academic areas.

2) Schools need to conduct regular workshops for parents to guide them on how to assist their children to acquire literacy skills. Parents could be sensitized on the importance of reading to children, listening to children read, consulting with teachers as well as checking of children's homework. Other interventions, such as showing interest in a child's academic work and provision of a literacy rich environment could be highlighted.

3) There is need to enhance community-school linkages to promote rapport between teachers and parents so as to achieve greater cooperation in the learning process.

\section{References}

[1] Savage, M. and Egerton, M. (1997) Social Mobility, Individual Ability and the Inheritance of Class inequality. Sociology, 31, 645-672. http://dx.doi.org/10.1177/0038038597031004002

[2] Pappas, G. (1976) Reading in the Primary School (New Edition). Macmillan, South Melbourne.

[3] Senechal, M. and LeFevre, J. (2002) Parental Involvement in the Development of Childrens Reading Skill: A Five Year Longitudinal Study. Child Development, 73, 445-460. http://dx.doi.org/10.1111/1467-8624.00417

[4] Whitehurst, G.J. and Lonigan, C.J. (1998) Child Development and Emergent Literacy. Child Development, 69, 848872.

[5] Uwezo, K. (2011) Annual Learning Assessment Kenya Report 2010. http://www.uwezo.net.

[6] Snow, C.E., Burns, M.S. and Griffin, P. (1998) Preventing Reading Difficulties in Your Children. National Academy Press, Washington DC.

[7] Mugenda, O. and Mugenda, A. (2003) Research Methods. Acts Press, Nairobi.

[8] Robb, L. (2003) Literacy Links. Heinenmann, Portsmouth.

[9] ASLA (2011) Report on the Impact of School Libraries on Student Achievement. http://www.asla.org.au

[10] Clay, M. (1991) Becoming Literate: The Construction of Inner Control. Heinemann,Auckland.

[11] Toomey, D. (1993) Parents Hearing Their Children Read: A Review. Rethinking theLessons of the Haringey Project. Educational Research, 35, 223-236. http://dx.doi.org/10.1080/0013188930350302

[12] Gianzero, G. (1999) Promoting Parental Involvement, Improving Students’ Outcomes. http://www.sandiegodialogue.org/pdfs 